\title{
Vasopressin $\mathbf{V}_{1 \mathrm{~A}}$ receptors mediate the increase in gastric mucosal oxygenation during hypercapnia
}

\author{
Christian Vollmer, Ingo Schwartges, Silke Naber, Christopher Beck, Inge Bauer \\ and Olaf Picker
}

Department of Anesthesiology, University Hospital Duesseldorf, Moorenstrasse 5, 40225 Duesseldorf, Germany
Correspondence should be addressed to $C$ Vollmer

Email

christian.vollmer@med. uni-duesseldorf.de

\begin{abstract}
Hypercapnia $(\mathrm{HC})$ improves systemic oxygen delivery $\left(\mathrm{DO}_{2}\right)$ and microvascular hemoglobin oxygenation of the mucosa $\left(\mu \mathrm{HbO}_{2}\right)$. Simultaneously, $\mathrm{HC}$ increases plasma levels of vasopressin. Although vasopressin is generally regarded a potent vasoconstrictor particularly in the splanchnic region, its effects on splanchnic microcirculation during $\mathrm{HC}$ is unclear. The aim of this study was to evaluate the role of endogenous vasopressin on gastric mucosal oxygenation and hemodynamic variables during physiological (normocapnia) and hypercapnic conditions. Five dogs were repeatedly anesthetized to study the effect of vasopressin $\mathrm{V}_{1 \mathrm{~A}}$ receptor blockade ([Pmp $\left.{ }^{1}, \mathrm{Tyr}(\mathrm{Me})^{2}\right]-\mathrm{Arg}^{8}$-Vasopressin, $\left.35 \mu \mathrm{g} / \mathrm{kg}\right)$ on hemodynamic variables and $\mu \mathrm{HbO}_{2}$ during normocapnia or $\mathrm{HC}$ (end-tidal $\mathrm{CO}_{2} 70 \mathrm{mmHg}$ ). In a control group, animals were subjected to $\mathrm{HC}$ alone. $\mu \mathrm{HbO}_{2}$ was measured by reflectance spectrophotometry, systemic $\mathrm{DO}_{2}$ was calculated from intermittent blood gas analysis, and cardiac output was measured by transpulmonary thermodilution. Data are presented as mean \pm s.E.M. for $n=5$ animals. During $\mathrm{HC}$ alone, $\mathrm{DO}_{2}$ increased from $12 \pm 1$ to $16 \pm 1 \mathrm{ml} / \mathrm{kg}$ per min and $\mu \mathrm{HbO}_{2}$ from $70 \pm 4$ to $80 \pm 2 \%$. By contrast, additional vasopressin $V_{1 \mathrm{~A}}$ receptor blockade abolished the increase in $\mu \mathrm{HbO}_{2}(80 \pm 2$ vs $69 \pm 2 \%)$ without altering the increase in $\mathrm{DO}_{2}(16 \pm 1$ vs $19 \pm$ $2 \mathrm{ml} / \mathrm{kg}$ per min). Vasopressin $\mathrm{V}_{1 \mathrm{~A}}$ receptor blockade (VB) during normocapnia neither affected $\mathrm{DO}_{2}\left(13 \pm 1 \mathrm{vs} 14 \pm 1 \mathrm{ml} / \mathrm{kg}\right.$ per $\min$ ) nor $\mu \mathrm{HbO}_{2}(75 \pm 3$ vs $71 \pm 5 \%)$. Vasopressin $\mathrm{V}_{1 \mathrm{~A}}$ receptor blockade abolished the increase in $\mu \mathrm{HbO}_{2}$ during $\mathrm{HC}$ independent of $\mathrm{DO}_{2}$. Thus, in contrast to its generally vasoconstrictive properties, the vasopressin $V_{1 A}$ receptors seem to mediate the increase in gastric microcirculatory mucosal oxygenation induced by acute $\mathrm{HC}$.
\end{abstract}

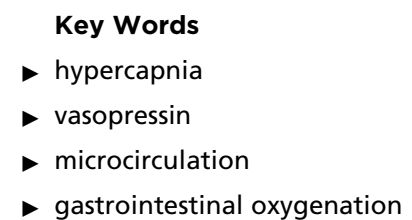

Journal of Endocrinology (2013) 217, 59-67

\section{Introduction}

The gastrointestinal tract is a complex organ system with multiple functions. Apart from being responsible for nutrient absorption, it is an important metabolic and immunological system, functioning as an effective barrier against endotoxin and bacteria from the intestinal lumen. To maintain this barrier, adequate perfusion and oxygenation of the mucosa are vital (Trzeciak et al. 2008).
However, during severe illness, the blood flow is redistributed to preserve perfusion of more vital organs (i.e. heart and brain) and thus splanchnic oxygenation is impaired early (Jakob \& Takala 2000, Schwartges et al. 2010). An impaired mucosal barrier function resulting from insufficient microcirculatory oxygen supply has been shown to enable translocation of bacteria and bacterial 
toxins into portal venous and local lymphatic circulation (Deitch et al. 2004) and to mediate an inflammatory response syndrome (Chen et al. 2003). Therefore, adequate splanchnic perfusion and in particular oxygenation of the gastrointestinal mucosa are considered crucial for the prevention and therapy of critical illness (Trzeciak et al. 2008). Thus, growing effort is made to develop strategies to improve splanchnic mucosal oxygenation.

In this context, we have recently shown that hypercapnia (HC) improves systemic oxygen delivery $\left(\mathrm{DO}_{2}\right)$ and microvascular oxygenation of the gastric mucosa not only during physiological conditions (Schwartges et al. 2008) but also during hemorrhagic shock (Schwartges et al. 2010). Apart from these effects on macro- and microcirculation, HC exerts multiple other changes in homeostasis, like an increase in vasopressin plasma level (Philbin et al. 1970, Forsling \& Rees 1975, Farber et al. 1982, Rose et al. 1984) with subsequent binding to the vasopressin $V_{1 \mathrm{~A}}$ receptors that could mediate or modulate the effects on microcirculation. Vasopressin is regarded as a potent vasoconstrictor particularly in the splanchnic region and reduces systemic $\mathrm{DO}_{2}$, cardiac output, and jejunal mucosal oxygen partial pressure (Knotzer et al. 2005). Thus, the positive effects on microcirculatory oxygenation induced by acute HC might be partially counteracted by an increase in vasopressin levels.

However, the effects of vasopressin on the splanchnic microcirculation were recently controversially discussed (Asfar et al. 2006). The expected negative effects of vasopressin could not be observed in a septic animal model (Knotzer et al. 2006) and even an improvement of gut microcirculatory flow is possible (Asfar et al. 2003). Furthermore, the effect seems to depend on flow. In animals with high systemic flow per se, gut microcirculatory flow was even increased additionally due to terlipressin (Asfar et al. 2003). By contrast, during low flow conditions, terlipressin infusion increased mortality (Asfar et al. 2003). However, despite its generally vasoconstrictive properties, vasopressin and its $\mathrm{V}_{1 \mathrm{~A}}$ receptor exert vasodilation as well (Evora et al. 1993). Little is known about the effect of exogenous vasopressin on regional oxygenation. The dosage applied seems to be an important factor, though studies are rare (Asfar et al. 2006). But most studies focused on macro- and microcirculatory hemodynamic variables (Asfar et al. 2008). Thus, the impact of endogenous vasopressin and its receptor on splanchnic oxygenation remains unclear, particularly during non-physiological situations like acute HC. The aim of our study was to evaluate the role of endogenous vasopressin during normoand HC on gastric mucosal oxygenation in healthy animals.

\section{Materials and methods}

\section{Animals}

The data were derived from repetitive experiments on five dogs (female foxhounds, weighing $28 \pm 1 \mathrm{~kg}$ ) treated in accordance with NIH guidelines for animal care and performed with approval of the local animal care and use committee.

Before the experiments, food was withheld for $12 \mathrm{~h}$ with water ad libitum to ensure complete gastric depletion and to avoid changes in perfusion and oxygenation due to digestive activity. Each dog underwent each experimental protocol in randomized order and served as its own control. Experiments were performed at least 3 weeks apart to prevent carryover effects. In each experiment, the dogs received an i.v. catheter that was removed at the end of the experiment. The experiments were performed under general anesthesia. General anesthesia was induced via the i.v. catheter (application of $4 \mathrm{mg} / \mathrm{kg}$ propofol) and maintained with inhalation of sevoflurane (end-tidal concentration 3.0\%, 1.5 minimum alveolar concentration (MAC) in dogs). The animals were mechanically ventilated after endotracheal intubation (semi-closed circle ventilation, inspiratory oxygen concentration $\mathrm{F}_{\mathrm{i}} \mathrm{O}_{2}=0.3$, tidal volume $=12.5 \mathrm{ml} / \mathrm{kg}$, a normal tidal volume for dogs) with the respiratory frequency adjusted to achieve normocapnia (end-expiratory concentration of $\mathrm{CO}_{2}$ et $\mathrm{O}_{2}=35 \mathrm{mmHg}$ ), verified by continuous capnography (Capnomac Ultima, Datex Instrumentarium, Helsinki, Finland). After induction of anesthesia and during the experiments, the dogs were placed on their right side covered with warming blankets to maintain body temperature within the physiological range for dogs (37-38.5 ${ }^{\circ} \mathrm{C}$, continuous arterial measurement). Throughout the experiments, no additional fluid replacement was administered to avoid volume effects that could influence tissue perfusion and oxygenation. However, after each blood withdrawal, normal saline was infused three times the sampling volume to maintain blood volume.

\section{Measurements}

Gastric mucosal oxygenation Microvascular oxygen saturation $\left(\mu \mathrm{HbO}_{2}\right)$ of the gastric mucosa was continuously assessed by tissue reflectance spectrophotometry (O2C, LEA Medizintechnik, Gießen, Germany), as detailed previously (Frank et al. 1989). Briefly, after induction of anesthesia, the flexible light-guide probe is introduced into the stomach non-traumatically via an orogastric

Published by Bioscientifica Ltd. 
silicone tube. White light $(450-1000 \mathrm{~nm})$ is transmitted to the tissue of interest, in this case the gastric mucosa, via the micro-light guide and the reflected light is then analyzed in vivo. The wavelength-dependent absorption of the applied white light can be used to calculate the percentage of oxygenated hemoglobin (Kuchenreuther et al. 1996).

As light is totally absorbed in vessels with a diameter $>100 \mu \mathrm{m}$, only microvascular oxygenation of nutritive vessels of the mucosa is measured. The biggest fraction of the blood volume is stored in venous vessels; therefore, mainly postcapillary oxygenation is measured that represents the critical partial pressure of oxygen $\left(\mathrm{pO}_{2}\right)$ for ischemia.

The flexible light-guide probe introduced into the stomach is positioned facing the greater curvature (Scheeren et al. 2002), a site demonstrated to represent the microvascular oxygenation of other gastric and upper intestinal mucosa regions (Temmesfeld-Wollbruck et al. 1998). Online evaluation of the signal quality throughout the experiments allows verification of the correct position of the probe tip. The $\mu \mathrm{HbO}_{2}$ values reported are the means of the last 5 min (150 spectra, $2 \mathrm{~s}$ each) of the respective intervention under steady state conditions. This method allows detection of splanchnic ischemia with similar precision as laser flowmetry (Leung et al. 1987), intra-vital microscopy (Bellamy et al. 1997), or hydrogen gas clearance (Machens et al. 1995). The non-traumatic instrumentation and in particular nontraumatic access to the gastric mucosa allows the determination of mucosal oxygenation in the absence of surgical stress. This is particularly desirable with respect to the marked alterations surgical stress exerts on splanchnic circulation (Gelman 1976). In this situation, reflectance spectrophotometry reliably detects even clinically asymptomatic reductions in mucosal oxygenation (Fournell et al. 2003) and highly correlates with the morphologic severity and extent of gastric mucosal tissue injury (Sato et al. 1986).

Systemic hemodynamics and oxygenation For continuous measurement of mean arterial pressure, a catheter (PiCCO 4.2 non-US, PULSION Medical Systems, Munich, Germany) was inserted via the left carotid artery into the aorta. This catheter was connected to a pressure transducer (MAP, Gould-Statham pressure transducers P23ID, Elk Grove, IL, USA) and mean arterial pressure was continuously recorded. Via this catheter, blood samples were withdrawn intermittently for measurement of blood gas tensions (arterial $\mathrm{CO}_{2}$ tension, arterial oxygen tension, and arterial oxygen saturation) and acidbase-related variables like $\mathrm{pH}$ and bicarbonate (Rapidlab 860, Bayer AG). Blood lactate concentrations could only be obtained in 13 of 15 experiments. Arterial oxygen content $\left(\mathrm{CaO}_{2}\right)$ and systemic $\mathrm{DO}_{2}\left(\mathrm{DO}_{2}=\mathrm{CaO}_{2} \times\right.$ cardiac output) were calculated. Cardiac output was determined via transpulmonary thermodilution (PiCCO 4.2) at the end of each intervention, at least every $30 \mathrm{~min}$, as described previously (von Spiegel et al. 1996). Briefly, cold saline was injected intravenously. The temperature of injected saline was measured at the injection site (PiCCO 4.2). The subsequent change in blood temperature measured at the site of the arterial catheter depends on cardiac output that was calculated with the Stewart-Hamilton equation.

Heart rate (HR) was continuously measured by electrocardiography (Powerlab, ADInstruments, Castle Hill, NSW, Australia). All hemodynamic and respiratory variables were recorded on a personal computer after analog to digital conversion (Powerlab, ADInstruments) for later analysis.

\section{Vasopressin receptor blockade}

Vasopressin receptor blockade was induced by i.v. infusion of $35 \mu \mathrm{g} / \mathrm{kg}\left[\mathrm{Pmp}^{1}, \mathrm{Tyr}(\mathrm{Me})^{2}\right]-\mathrm{Arg}^{8}$-Vasopressin (Peptide Institute, Inc., 4-1-2 Ina, Minoh-shi Osaka, 562-8686, Japan), a selective $\mathrm{V}_{1 \mathrm{~A}}$ receptor antagonist (Howl \& Wheatley 1995), as single dose. Complete receptor blockade was confirmed by administration of vasopressin (250 $\mathrm{mU},\left[\mathrm{Arg}^{8}\right]$-Vasopressin, Sigma-Aldrich) at the end of each experiment. This dose had no effect on hemodynamic variables at the end of the observation period but increased mean arterial pressure by about $20 \mathrm{mmHg}$ without preceding vasopressin receptor blockade.

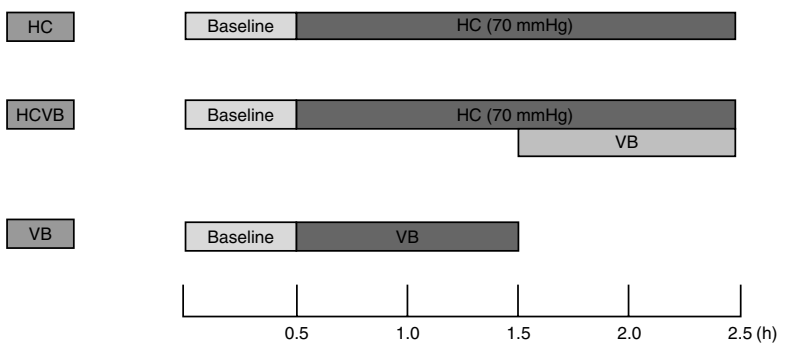

Figure 1

Experimental protocol: hypercapnia per se $(\mathrm{HC}), \mathrm{HC}$ with subsequent vasopressin receptor blockade (HCVB), and vasopressin receptor blockade (VB) during normocapnia in dogs.

Published by Bioscientifica Ltd. 


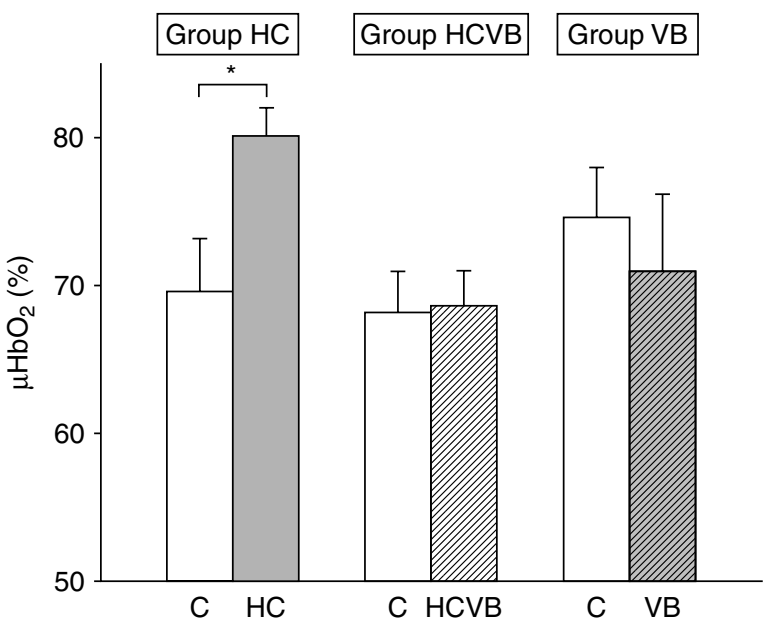

\section{Figure 2}

Microvascular hemoglobin oxygenation. Effects on microvascular hemoglobin oxygenation $\left(\mu \mathrm{HbO}_{2}\right)$ during hypercapnia $(\mathrm{HC}), \mathrm{HC}$ with subsequent vasopressin receptor blockade (HCVB), and vasopressin receptor blockade during normocapnia (VB) with corresponding baseline values (C) in dogs. Data are presented as absolute values for $n=5$ dogs, mean \pm S.E.M., $* P<0.05$

\section{Vasopressin plasma level}

Vasopressin plasma levels during HC were determined only exemplarily in single experiments because increase in vasopressin plasma levels during $\mathrm{HC}$ has been observed before (Philbin et al. 1970, Forsling \& Rees 1975, Farber et al. 1982, Rose et al. 1984). Blood samples were collected in EDTA-containing tubes, immediately centrifuged, and stored at $-20^{\circ} \mathrm{C}$ for later analysis by an external laboratory (Labor Limbach, Heidelberg, Germany). Vasopressin plasma levels during vasopressin receptor blockade are not of informative value and were not determined.

\section{Experimental program}

Following the instrumentation, 30 min were allowed to establish steady state conditions and baseline values were recorded before the animals were randomized to the respective protocol (Fig. 1).

Hypercapnia (HC) As control group, effects of HC on $\mu \mathrm{HbO}_{2}$ were tested without vasopressin receptor blockade. End-tidal $\mathrm{CO}_{2}$ was continuously increased from 35 to $70 \mathrm{mmHg}$ over $30 \mathrm{~min}$ via reduction in respiratory frequency as described previously (Schwartges et al. 2008). HC was maintained for $2 \mathrm{~h}$.
Vasopressin receptor blockade during hypercapnia (HCVB) To analyze the effects of $\mathrm{HC}$ during vasopressin $\mathrm{V}_{1 \mathrm{~A}}$ receptor blockade (HCVB), $\mathrm{HC}$ was induced as in control experiments. After $60 \mathrm{~min}$ of $\mathrm{HC}$, vasopressin $\mathrm{V}_{1 \mathrm{~A}}$ receptor blockade was initiated as described earlier with an additional observation period of $60 \mathrm{~min}$.

Vasopressin receptor blockade (VB) Effects of vasopressin $\mathrm{V}_{1 \mathrm{~A}}$ receptor blockade alone were tested during normocapnia. After baseline conditions, vasopressin $V_{1 A}$ receptor blockade was initiated as described earlier with an additional observation period of $60 \mathrm{~min}$. At the end of each intervention, blood samples were obtained for blood gas analysis.

\section{Statistical analysis}

Data for analysis were obtained during the last 5 min of each intervention under steady state conditions. Normal data distribution was assessed in Q-Q plots (IBM SPSS Statistics, International Business Machine Corp.). All data are presented as absolute values of mean ( \pm s.e.M.) for $n=5$ animals. Differences within the groups and between the groups were tested using an ANOVA for repeated measurements (ANOVA) and a Fisher's PLSD test as post hoc test (StatView V4.1, SAS Institute Inc., Cary, NC, USA); $P<0.05$ was considered significant.

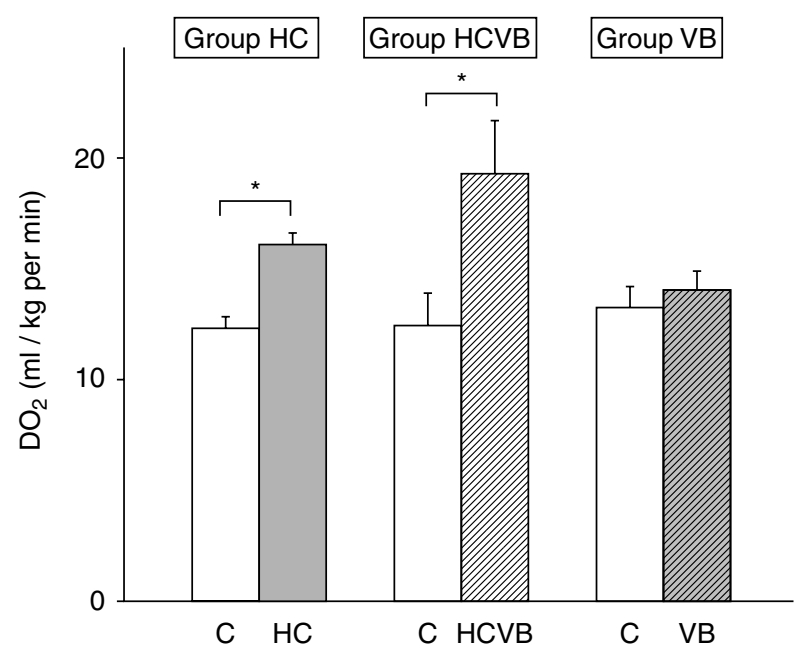

Figure 3

Systemic oxygen delivery $\left(\mathrm{DO}_{2}\right)$. Effects on systemic $\mathrm{DO}_{2}$ during hypercapnia (HC), HC with subsequent vasopressin receptor blockade (HCVB), or vasopressin receptor blockade during normocapnia (VB) with corresponding baseline values $(C)$ in dogs. Data are presented as absolute values for $n=5$ dogs, mean \pm s.E.M., $* P<0.05$.

Published by Bioscientifica Ltd 


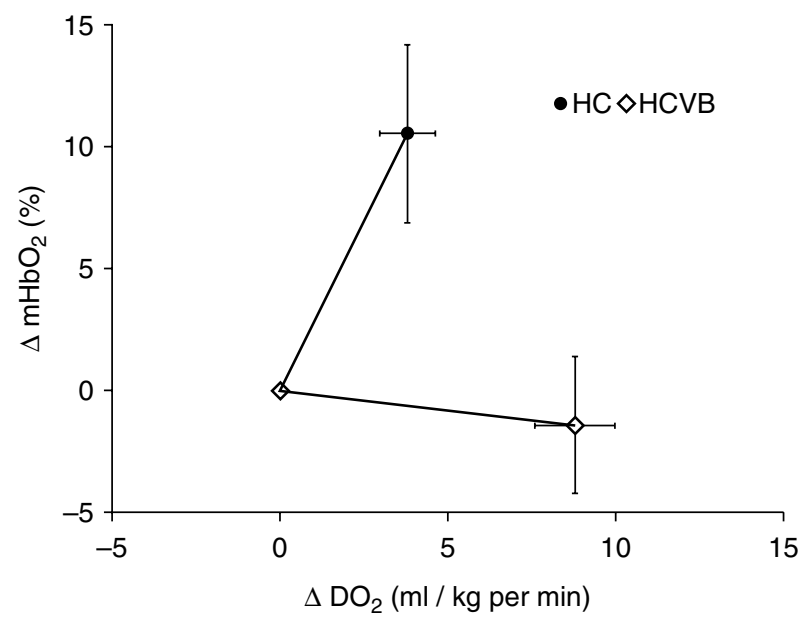

Figure 4

Relationship between mucosal oxygenation and systemic oxygen transport. Relationship between regional mucosal oxygenation $\left(\mu \mathrm{HbO}_{2}\right)$ and systemic oxygen transport $\left(\mathrm{DO}_{2}\right)$ under hypercapnia $(\mathrm{HC}$, group $\mathrm{HC})$ and $\mathrm{HC}$ with subsequent vasopressin receptor blockade (HCVB, group HCVB) in dogs. To compensate for individual baseline differences, the respective effects were zero-referenced in this figure.

\section{Results}

$\mathrm{HC}$ increased $\mu \mathrm{HbO}_{2}$ from $70 \pm 4$ to $80 \pm 2 \%$ after $2 \mathrm{~h}$ of $\mathrm{HC}$ (Fig. 2). Subsequent vasopressin $\mathrm{V}_{1 \mathrm{~A}}$ receptor blockade (HCVB) abolished the HC-induced increase in $\mu \mathrm{HbO}_{2}$ ( $80 \pm 2$ vs $69 \pm 2 \%$ ). By contrast, vasopressin $V_{1 \mathrm{~A}}$ receptor blockade (VB) during normocapnia had no effect on $\mu \mathrm{HbO}_{2}$ (75 \pm 3 vs $\left.71 \pm 5 \%\right)$.

During HC, systemic $\mathrm{DO}_{2}$ increased from $12 \pm 1$ to $16 \pm 1 \mathrm{ml} / \mathrm{kg}$ per min similar to the increase in $\mu \mathrm{HbO}_{2}$. This increase mainly resulted from increased cardiac output during $\mathrm{HC}$ (from $86 \pm 6$ to $111 \pm 8 \mathrm{ml} / \mathrm{kg}$ per $\mathrm{min}$ ). However, while the increase in $\mu \mathrm{HbO}_{2}$ was abolished during additional vasopressin $\mathrm{V}_{1 \mathrm{~A}}$ receptor blockade, $\mathrm{DO}_{2}$ increased both during $\mathrm{HC}$ and vasopressin $\mathrm{V}_{1 \mathrm{~A}}$ receptor blockade (Fig. 3). The relationship between $\mu \mathrm{HbO}_{2}$ and $\mathrm{DO}_{2}$ is shown in Fig. 4. HC with intact vasopressin system increases $\mu \mathrm{HbO}_{2}$ and $\mathrm{DO}_{2}$ in parallel, while during vasopressin $\mathrm{V}_{1 \mathrm{~A}}$ receptor blockade $\mathrm{HC}$ selectively increased $\mathrm{DO}_{2}$. Cardiac output increased both during $\mathrm{HC}$ and vasopressin $\mathrm{V}_{1 \mathrm{~A}}$ receptor blockade (from $80 \pm 8$ to $118 \pm 10 \mathrm{ml} / \mathrm{kg}$ per min). The increase in cardiac output both under $\mathrm{HC}$ and $\mathrm{HC}$ with vasopressin $\mathrm{V}_{1 \mathrm{~A}}$ receptor blockade is related to a similar increase in stroke volume (from $23 \pm 2$ and $22 \pm 2$ to $29 \pm 3$ and $29 \pm 3 \mathrm{ml}$ respectively) without differences between both groups. The additional increase in $\mathrm{CO}$ and $\mathrm{DO}_{2}$ in group HCVB could be attributed to the changes in HR, which did not change during HC (104 \pm 4 to $109 \pm 5$ per min) but significantly increased during additional vasopressin $\mathrm{V}_{1 \mathrm{~A}}$ receptor blockade (104 \pm 3 to $113 \pm 4$ per $\min$ ).

By contrast, during vasopressin $\mathrm{V}_{1 \mathrm{~A}}$ receptor blockade under physiological conditions, $\mathrm{DO}_{2}$ remained unchanged according to cardiac output, which did not change either. Likewise, neither HR nor stroke volume changed.

Systemic vascular resistance (SVR) decreased in the HC and HCVB groups; however, SVR tended to be lower in the HCVB group, while vasopressin $\mathrm{V}_{1 \mathrm{~A}}$ receptor blockade under normocapnic conditions did not change SVR.

Arterial $\mathrm{CO}_{2}$ tension $\left(\mathrm{P}_{\mathrm{a}} \mathrm{CO}_{2}\right)$ was increased in the hypercapnic groups and $\mathrm{pH}$ was accordingly reduced. This was not influenced by vasopressin $\mathrm{V}_{1 \mathrm{~A}}$ receptor blockade. Blood lactate concentrations remained almost unchanged in all groups. Vasopressin $\mathrm{V}_{1 \mathrm{~A}}$ receptor blockade under physiological conditions did not affect blood gas tensions. Further hemodynamic variables are shown in Table 1 and blood gas tensions in Table 2.

\section{Vasopressin plasma levels}

In two representative pilot experiments, vasopressin plasma levels increased from $17 \mathrm{ng} / \mathrm{ml}$ in one animal

Table 1 Microvascular oxygenation and hemodynamic variables in dogs. Effects on systemic vascular resistance (SVR), cardiac output (CO), stroke volume (SV), mean arterial pressure (MAP), and heart rate (HR) during vasopressin blockade during normocapnia (VB) and during hypercapnia (HCVB) as well as hypercapnia per se $(\mathrm{HC})$; data presented as absolute values, $n=5$, mean \pm s.E.M.

\begin{tabular}{|c|c|c|c|}
\hline Variable & Group & Baseline & $\begin{array}{l}\text { Endpoint } \\
( \pm H C \pm V B)\end{array}$ \\
\hline \multirow[t]{3}{*}{ SVR $(\mathrm{mmHg} / \mathrm{l}$ per min) } & $\mathrm{HC}$ & $26 \pm 2$ & $23 \pm 2 *$ \\
\hline & HCVB & $29 \pm 3$ & $22 \pm 2 *$ \\
\hline & VB & $29 \pm 2$ & $27 \pm 1$ \\
\hline \multirow[t]{3}{*}{$\mathrm{CO}(\mathrm{ml} / \mathrm{kg}$ per $\mathrm{min})$} & $\mathrm{HC}$ & $86 \pm 6$ & $111 \pm 8 *$ \\
\hline & HCVB & $80 \pm 8$ & $118 \pm 10$ * \\
\hline & VB & $81 \pm 6$ & $84 \pm 4$ \\
\hline \multirow[t]{3}{*}{$\mathrm{SV}(\mathrm{ml})$} & $\mathrm{HC}$ & $23 \pm 2$ & $29 \pm 3 *$ \\
\hline & HCVB & $22 \pm 2$ & $29 \pm 3 *$ \\
\hline & VB & $21 \pm 2$ & $22 \pm 1$ \\
\hline \multirow[t]{3}{*}{ MAP $(\mathrm{mmHg})$} & $\mathrm{HC}$ & $62 \pm 2$ & $69 \pm 3 *$ \\
\hline & HCVB & $61 \pm 2$ & $70 \pm 2 *$ \\
\hline & VB & $64 \pm 1$ & $63 \pm 1$ \\
\hline \multirow[t]{3}{*}{ HR (per min) } & $\mathrm{HC}$ & $104 \pm 4$ & $109 \pm 5$ \\
\hline & HCVB & $104 \pm 3$ & $113 \pm 4 *$ \\
\hline & VB & $108 \pm 2$ & $110 \pm 4$ \\
\hline
\end{tabular}

${ }^{*} P<0.05$ vs baseline.

Published by Bioscientifica Ltd 
Table 2 Blood gas tensions, $\mathrm{pH}$, bicarbonate, hemoglobin, lactate, and potassium in dogs. Effects of vasopressin receptor blockade on arterial oxygen saturation $\left(\mathrm{S}_{\mathrm{a}} \mathrm{O}_{2}\right)$, arterial $\mathrm{CO}_{2}$ tension $\left(\mathrm{P}_{\mathrm{a}} \mathrm{CO}_{2}\right)$, arterial oxygen tension $\left(\mathrm{P}_{\mathrm{a}} \mathrm{O}_{2}\right), \mathrm{pH}, \mathrm{HCO}_{3}{ }^{-}$, hemoglobin $(\mathrm{Hb})$, lactate, and potassium $\left(\mathrm{K}^{+}\right)$during normocapnia (VB) and during hypercapnia (HCVB) as well as hypercapnia per se $(\mathrm{HC})$; data presented as absolute values, $n=5$, mean \pm s.E.M.

\begin{tabular}{|c|c|c|c|}
\hline Variable & Group & Baseline & $\begin{array}{l}\text { Endpoint } \\
(H C \pm V B)\end{array}$ \\
\hline \multirow[t]{3}{*}{$\mathrm{S}_{\mathrm{a}} \mathrm{O}_{2}(\%)$} & $\mathrm{HC}$ & $98 \pm 1$ & $95 \pm 1 *$ \\
\hline & HCVB & $99 \pm 1$ & $96 \pm 1$ * \\
\hline & VB & $99 \pm 1$ & $99 \pm 1$ \\
\hline \multirow[t]{3}{*}{$\mathrm{P}_{\mathrm{a}} \mathrm{CO}_{2}(\mathrm{mmHg})$} & $\mathrm{HC}$ & $39 \pm 1$ & $67 \pm 1 *$ \\
\hline & HCVB & $39 \pm 1$ & $66 \pm 1 *$ \\
\hline & VB & $38 \pm 1$ & $39 \pm 1$ \\
\hline \multirow[t]{3}{*}{$\mathrm{P}_{\mathrm{a}} \mathrm{O}_{2}(\mathrm{mmHg})$} & $\mathrm{HC}$ & $154 \pm 5$ & $119 \pm 6^{*}$ \\
\hline & HCVB & $153 \pm 4$ & $120 \pm 3 *$ \\
\hline & VB & $153 \pm 3$ & $155 \pm 4$ \\
\hline \multirow[t]{3}{*}{$\mathrm{pH}$} & $\mathrm{HC}$ & $7.33 \pm 0.01$ & $7.15 \pm 0.01 *$ \\
\hline & HCVB & $7.37 \pm 0.01^{\dagger}$ & $7.18 \pm 0.01 *+$ \\
\hline & VB & $7.4 \pm 0.01$ & $7.4 \pm 0.01$ \\
\hline \multirow[t]{3}{*}{$\mathrm{HCO}_{3}{ }^{-}(\mathrm{mmol} / \mathrm{l})$} & $\mathrm{HC}$ & $20 \pm 1$ & $23 \pm 1 *$ \\
\hline & HCVB & $22 \pm 1^{\dagger}$ & $24 \pm 1 *^{+}$ \\
\hline & VB & $23 \pm 1$ & $23 \pm 1$ \\
\hline \multirow[t]{3}{*}{$\mathrm{Hb}(\mathrm{g} / 100 \mathrm{ml})$} & $\mathrm{HC}$ & $11 \pm 1$ & $11 \pm 1 *$ \\
\hline & HCVB & $12 \pm 1$ & $12 \pm 1 *$ \\
\hline & VB & $12 \pm 1$ & $12 \pm 1$ \\
\hline \multirow[t]{3}{*}{ Lactate $(\mathrm{mmol} / \mathrm{l})$} & $\mathrm{HC}$ & $2.1 \pm 0.3$ & $1.2 \pm 0.1 *$ \\
\hline & HCVB & $1.9 \pm 0.2$ & $0.8 \pm 0.1^{*, \dagger}$ \\
\hline & VB & $1.6 \pm 0.4$ & $1.4 \pm 0.3$ \\
\hline \multirow[t]{3}{*}{$\mathrm{K}^{+}(\mathrm{mmol} / \mathrm{l})$} & $\mathrm{HC}$ & $4.0 \pm 0.1$ & $4.3 \pm 0.1$ * \\
\hline & HCVB & $3.9 \pm 0.1$ & $4.4 \pm 0.1 *$ \\
\hline & VB & $3.9 \pm 0.1$ & $4.1 \pm 0.1$ * \\
\hline
\end{tabular}

${ }^{*} P<0.05$ vs baseline, ${ }^{\dagger} P<0.05$ vs $\mathrm{HC}$ group at the same time.

and $13 \mathrm{ng} / \mathrm{ml}$ in another one under baseline conditions to 33 and $22 \mathrm{ng} / \mathrm{ml}$ after $30 \mathrm{~min}$ of $\mathrm{HC}$ and was almost doubled after $60 \mathrm{~min}$ of $\mathrm{HC}$ ( 34 and $24 \mathrm{ng} / \mathrm{ml}$ ).

\section{Discussion}

\section{Interpretation of the results}

The main results from our experiments are that i) vasopressin $V_{1 A}$ receptor blockade abolished the increase in gastric mucosal oxygenation during HC. ii) $\mathrm{DO}_{2}$ increased during vasopressin $\mathrm{V}_{1 \mathrm{~A}}$ receptor blockade under $\mathrm{HC}$ without effect on $\mu \mathrm{HbO}_{2}$. iii) Vasopressin $\mathrm{V}_{1 \mathrm{~A}}$ receptor blockade did not alter systemic or regional microcirculation during normocapnic (physiological) conditions.

The results lead to the following conclusions that will be discussed in detail.
1. Vasopressin $\mathrm{V}_{1 \mathrm{~A}}$ receptors mediate hypercapnic increases in gastric mucosal oxygenation.

2. $\mathrm{HC}$ modulates $\mu \mathrm{HbO}_{2}$ mainly independently of systemic $\mathrm{DO}_{2}$.

3. Vasopressin $\mathrm{V}_{1 \mathrm{~A}}$ receptors are not involved in regulation of gastrointestinal microvascular oxygenation under physiological conditions.

The vasopressin $\mathrm{V}_{1 \mathrm{~A}}$ receptors are responsible for the increase in $\mu \mathrm{HbO}_{2}$ during $\mathrm{HC}$. This effect might be related to an increase in endogenous vasopressin. In our study, vasopressin plasma levels seemed to increase during $\mathrm{HC}$ as measured exemplarily only in two representative experiments without statistical analysis because increase in vasopressin plasma levels during $\mathrm{HC}$ is already well known (Philbin et al. 1970, Forsling \& Rees 1975, Farber et al. 1982, Rose et al. 1984). Although the relation between increased vasopressin plasma levels and the effect of the $V_{1 \mathrm{~A}}$ receptors might indicate an effect of vasopressin, we cannot exclude the effect of other possible ligands, e.g. oxytocin, on the receptor. However, vasopressin has a 30 -fold higher affinity to the receptor than oxytocin (Holmes et al. 2003), indicating a rather minor role of oxytocin. Additionally, one study suggests that vasodilatory effects of the $V_{1}$ receptors are linked to binding of vasopressin (Evora et al. 1993).

This supports the hypothesis that the increase in gastric mucosal oxygenation via the $\mathrm{V}_{1 \mathrm{~A}}$ receptors might be mediated by an increase in vasopressin, although the application of exogenous vasopressin exerts rather negative effects on splanchnic perfusion. However, vasopressin is known to have vasodilatory properties as well (Holmes et al. 2003).

Accordingly, many studies have recently shown that effects of vasopressin are not confined to vasoconstriction in the splanchnic region solely and our study contributes another novel fact to the unexpected new understanding of vasopressin and its receptor (Asfar et al. 2006). While vasopressin is known to jeopardize splanchnic circulation (Knotzer et al. 2005), this effect is abolished in the same model during endotoxemia (Knotzer et al. 2006). Another study using terlipressin has shown even increased hepatic arterial blood flow with unaffected splanchnic $\mathrm{DO}_{2}$ (Asfar et al. 2005). On the other hand, cardiac output decreased in several studies (Knotzer et al. 2005). This was not the case in our study under physiological conditions, probably because we did not apply vasopressin exogenously. Another explanation might be that physiological plasma levels are too low to exert those effects. During HC - and hence higher vasopressin plasma levels - receptor

Published by Bioscientifica Ltd 
blockade increased $\mathrm{CO}$ in our model concordant with the mentioned studies. Thus, once activated, release of vasopressin exerts substantial effects on cardiac output and splanchnic circulation. Therefore, those effects seem to be concentration dependent and vasopressin plasma levels under physiological conditions do not exert substantial effects on cardiac output and splanchnic circulation. Concentration-dependent effects of vasopressin have been observed in human beings as well (Russell 2011). Additionally, effects of vasopressin differ between organs and therefore different splanchnic organs have to be regarded separately (Asfar et al. 2006).

Nevertheless, vasopressin $\mathrm{V}_{1 \mathrm{~A}}$ receptor blockade might increase vasopressin binding to the other vasopressin receptors. But other receptors are either not involved in regulation of vascular tone or - in case of endothelial oxytocin receptors and $\mathrm{V}_{2}$ receptors - mediate vasodilation (Holmes et al. 2004). Increased binding to other receptors would thus rather increase $\mu \mathrm{HbO}_{2}$ during HC instead of abolishing this effect.

The effect of the vasopressin $V_{1 A}$ receptor on gastric oxygenation during $\mathrm{HC}$ seems to be confined to regional hemodynamic variables as vasopressin receptor blockade during $\mathrm{HC}$ solely affects $\mu \mathrm{HbO}_{2}$ and does not reduce any of the other parameters like cardiac output or systemic oxygen transport that could have been an alternative reason for changes in $\mu \mathrm{HbO}_{2}$.

An alternative explanation for the increased $\mu \mathrm{HbO}_{2}$ might be an increased shunting of oxygen to the venular compartment, which represents the biggest fraction of $\mu \mathrm{HbO}_{2}$. However, in this case, lactate levels might increase as an indicator of insufficient oxygen supply, which could not be observed (Table 2). Thus, the reason for these unexpected results might rather be a vasopressin receptormediated redistribution of cardiac output (Asfar et al. 2008) in favor of gastric mucosa during HC. However, this remains speculative as we do not have any direct evidence. During $\mathrm{HC}$ and vasopressin $\mathrm{V}_{1 \mathrm{~A}}$ receptor blockade, the increased systemic $\mathrm{DO}_{2}$ does not seem to reach the gastric mucosal microcirculation (Fig. 4). Redistribution of cardiac output might be due to different vasopressin receptor expression, which can be decreased, e.g. in models of sepsis. Whether vasopressin receptor expression is decreased during $\mathrm{HC}$ as well is so far unknown.

Each dog underwent each protocol in a randomized order and hence served as its own control. Therefore, interindividual differences can be eliminated. This approach allows use of a small group size of $n=5$ animals.

Thus, the results from this study extend our knowledge from previous studies. Vasopressin is increased during epidural anesthesia to maintain blood pressure (Picker et al. 2001). Additionally, it is increased during anesthesia with high doses (3 MAC) of sevoflurane (Picker et al. 2004). With regard to our results, the role of vasopressin and its receptor seems to be of minor importance under physiological conditions with low vasopressin plasma levels, but it is necessary, e.g. to maintain blood pressure, under a variety of pathological conditions. According to our results, $\mathrm{HC}$ is one of those pathological conditions with major importance of vasopressin that exerts so far unknown properties.

\section{Clinical impact}

Our results indicate one new possible mechanism of hypercapnic improvement of microcirculatory oxygenation and demonstrate for the first time a new role of the $\mathrm{V}_{1 \mathrm{~A}}$ receptors in regulating splanchnic oxygenation apart from vasoconstriction. This is of particular interest as permissive $\mathrm{HC}$ is widely used in the intensive care unit especially in critically ill patients, e.g. sepsis-associated acute respiratory distress syndrome (ARDS) and exogenous vasopressin remains a possible therapeutic option for severe hemodynamic instability. Thus, it is important to know about the interaction of $\mathrm{HC}$ with vasopressin and about the effects on splanchnic oxygenation, which is vital for these patients in particular. However, especially in these patients, vasopressin maintains systemic blood pressure at the expense of splanchnic microcirculation, which is normally impaired due to vasopressin (Boerma et al. 2005). Still, despite clinical trials, there is no definite answer to whether vasopressin affects mortality.

The effect of $\mathrm{HC}$ on $\mu \mathrm{HbO}_{2}$ can still be observed during hemorrhagic shock (Schwartges et al. 2010), a situation that leads to extended release of vasopressin with subsequent binding to the vasopressin $\mathrm{V}_{1 \mathrm{~A}}$ receptors (Fujisawa et al. 1994). Whether this extended release of vasopressin is involved in increasing $\mu \mathrm{HbO}_{2}$ during hemorrhage has to be studied yet but might lead to further interesting results of clinical importance.

Summarizing recently published studies, it still seems difficult to draw a definite conclusion on the effects of vasopressin on splanchnic hemodynamics (Asfar et al. 2008). While many studies analyzed effects of exogenous vasopressin with diverse results, our study helps to understand physiological effects of vasopressin $V_{1 A}$ receptors on splanchnic hemodynamics during physiological and hypercapnic conditions. In addition, most studies focused on macro- and microcirculatory hemodynamic variables, while only some studies addressed

Published by Bioscientifica Ltd. 
local oxygenation (Asfar et al. 2008). Thus, our results provide first evidence of the vasopressin $\mathrm{V}_{1 \mathrm{~A}}$ receptors to increase regional oxygenation during $\mathrm{HC}$.

\section{Conclusions}

Vasopressin $\mathrm{V}_{1 \mathrm{~A}}$ receptor blockade during $\mathrm{HC}$ suppressed the $\mathrm{HC}$-induced increase in $\mu \mathrm{HbO}_{2}$. Thus, in contrast to its generally vasoconstrictive properties, the vasopressin $\mathrm{V}_{1 \mathrm{~A}}$ receptors seem to mediate hypercapnic increase in gastric mucosal oxygenation. This increase in $\mu \mathrm{HbO}_{2}$ during $\mathrm{HC}$ is independent of systemic oxygen transport.

\section{Declaration of interest}

The authors declare that there is no conflict of interest that could be perceived as prejudicing the impartiality of the research reported.

\section{Funding}

This research did not receive any specific grant from any funding agency in the public, commercial, or not-for-profit sector.

\section{Acknowledgements}

The authors thank Dr Pablo Verde (Head of Biostatistics, Coordinating Centre for Clinical Trials, University Hospital Duesseldorf) for guidance and review of statistical analysis.

\section{References}

Asfar P, Pierrot M, Veal N, Moal F, Oberti F, Croquet V, Douay O, Gallois Y, Saumet JL, Alquier P et al. 2003 Low-dose terlipressin improves systemic and splanchnic hemodynamics in fluid-challenged endotoxic rats. Critical Care Medicine 31 215-220. (doi:10.1097/00003246-20030100000033)

Asfar P, Hauser B, Ivanyi Z, Ehrmann U, Kick J, Albicini M, Vogt J, Wachter U, Bruckner UB, Radermacher P et al. 2005 Low-dose terlipressin during long-term hyperdynamic porcine endotoxemia: effects on hepatosplanchnic perfusion, oxygen exchange, and metabolism. Critical Care Medicine 33 373-380. (doi:10.1097/ 01.CCM.0000152253.45901.FB)

Asfar P, Radermacher P \& Hauser B 2006 Vasopressin and splanchnic blood flow: vasoconstriction does not equal vasoconstriction in every organ. Intensive Care Medicine 32 21-23. (doi:10.1007/s00134-005-2867-y)

Asfar P, Bracht H \& Radermacher P 2008 Impact of vasopressin analogues on the gut mucosal microcirculation. Best Practice \& Research. Clinical Anaesthesiology 22 351-358. (doi:10.1016/j.bpa.2008.02.009)

Bellamy MC, Mullane D, O’Beirne HA, Young Y, Pollard SG \& Lodge JP 1997 Dopexamine and microcirculatory flow in transplanted small bowel: the Leeds experience. Transplantation Proceedings 29 1847-1849. (doi:10.1016/S0041-1345(97)00093-6)

Boerma EC, van der Voort PH \& Ince C 2005 Sublingual microcirculatory flow is impaired by the vasopressin-analogue terlipressin in a patient with catecholamine-resistant septic shock. Acta Anaesthesiologica Scandinavica 49 1387-1390. (doi:10.1111/j.1399-6576.2005.00752.x)

Chen LW, Egan L, Li ZW, Greten FR, Kagnoff MF \& Karin M 2003 The two faces of IKK and NF-kappaB inhibition: prevention of systemic inflammation but increased local injury following intestinal ischemiareperfusion. Nature Medicine 9 575-581. (doi:10.1038/nm849)

Deitch EA, Forsythe R, Anjaria D, Livingston DH, Lu Q, Xu DZ \& Redl H 2004 The role of lymph factors in lung injury, bone marrow suppression, and endothelial cell dysfunction in a primate model of trauma-hemorrhagic shock. Shock 22 221-228. (doi:10.1097/01.shk. 0000133592.55400.83)

Evora PR, Pearson PJ \& Schaff HV 1993 Arginine vasopressin induces endothelium-dependent vasodilatation of the pulmonary artery. V1-receptor-mediated production of nitric oxide. Chest $\mathbf{1 0 3}$ 1241-1245. (doi:10.1378/chest.103.4.1241)

Farber MO, Roberts LR, Weinberger MH, Robertson GL, Fineberg NS \& Manfredi F 1982 Abnormalities of sodium and $\mathrm{H}_{2} \mathrm{O}$ handling in chronic obstructive lung disease. Archives of Internal Medicine 142 1326-1330. (doi:10.1001/archinte.1982.00340200086019)

Forsling ML \& Rees M 1975 Proceedings: effects of hypoxia and hypercapnia on plasma vasopressin concentration. Journal of Endocrinology 67 62P-63P.

Fournell A, Schwarte LA, Kindgen-Milles D, Muller E \& Scheeren TW 2003 Assessment of microvascular oxygen saturation in gastric mucosa in volunteers breathing continuous positive airway pressure. Critical Care Medicine 31 1705-1710. (doi:10.1097/01.CCM.0000063281.47070.53)

Frank KH, Kessler M, Appelbaum K \& Dummler W 1989 The Erlangen micro-lightguide spectrophotometer EMPHO I. Physics in Medicine and Biology 34 1883-1900. (doi:10.1088/0031-9155/34/12/011)

Fujisawa Y, Miyatake A, Hayashida Y, Aki Y, Kimura S, Tamaki T \& Abe Y 1994 Role of vasopressin on cardiovascular changes during hemorrhage in conscious rats. American Journal of Physiology 267 H1713-H1718.

Gelman SI 1976 Disturbances in hepatic blood flow during anesthesia and surgery. Archives of Surgery 111 881-883. (doi:10.1001/archsurg.1976. 01360260049012)

Holmes CL, Landry DW \& Granton JT 2003 Science review: vasopressin and the cardiovascular system part 1 - receptor physiology. Critical Care $\mathbf{7}$ 427-434. (doi:10.1186/cc2337)

Holmes CL, Landry DW \& Granton JT 2004 Science review: vasopressin and the cardiovascular system part 2 - clinical physiology. Critical Care $\mathbf{8}$ 15-23. (doi:10.1186/cc2338)

Howl J \& Wheatley M 1995 Molecular pharmacology of V1a vasopressin receptors. General Pharmacology 26 1143-1152. (doi:10.1016/03063623(95)00016-T)

Jakob SM \& Takala J 2000 Gut perfusion in the critically ill. Intensive Care Medicine 26 813-815. (doi:10.1007/s001340051253)

Knotzer H, Pajk W, Maier S, Ladurner R, Kleinsasser A, Wenzel V, Dunser MW, Ulmer H \& Hasibeder WR 2005 Arginine vasopressin reduces intestinal oxygen supply and mucosal tissue oxygen tension. American Journal of Physiology. Heart and Circulatory Physiology 289 H168-H173. (doi:10.1152/ajpheart.01235.2004)

Knotzer H, Maier S, Dunser MW, Hasibeder WR, Hausdorfer H, Brandner J, Torgersen C, Ulmer H, Friesenecker B, Iannetti C et al. 2006 Arginine vasopressin does not alter mucosal tissue oxygen tension and oxygen supply in an acute endotoxemic pig model. Intensive Care Medicine 32 170-174. (doi:10.1007/s00134-005-2858-z)

Kuchenreuther S, Adler J, Schutz W, Eichelbronner O \& Georgieff M 1996 The Erlanger Microlightguide Photometer: a new concept for monitoring intracapillary oxygen supply of tissue - first results and a review of the physiological basis. Journal of Clinical Monitoring 12 211-224. (doi:10.1007/BF00857642)

Leung FW, Morishita T, Livingston EH, Reedy T \& Guth PH 1987 Reflectance spectrophotometry for the assessment of gastroduodenal mucosal perfusion. American Journal of Physiology 252 G797-G804.

Machens HG, Pallua N, Mailaender P, Pasel J, Frank KH, Reimer R \& Berger A 1995 Measurements of tissue blood flow by the hydrogen clearance technique (HCT): a comparative study including laser Doppler flowmetry (LDF) and the Erlangen micro-lightguide spectrophotometer (EMPHO). Microsurgery 16 808-817. (doi:10.1002/ micr.1920161208) 
Philbin DM, Baratz RA \& Patterson RW 1970 The effect of carbon dioxide on plasma antidiuretic hormone levels during intermittent positivepressure breathing. Anesthesiology 33 345-349. (doi:10.1097/00000542197009000-00016)

Picker O, Schindler AW \& Scheeren TW 2001 Endogenous endothelin and vasopressin support blood pressure during epidural anesthesia in conscious dogs. Anesthesia and Analgesia 93 1580-1586 table of contents. (doi:10.1097/00000539-200112000-00054)

Picker O, Schwarte LA, Roth HJ, Greve J \& Scheeren TW 2004 Comparison of the role of endothelin, vasopressin and angiotensin in arterial pressure regulation during sevoflurane anaesthesia in dogs. British Journal of Anaesthesia 92 102-108. (doi:10.1093/bja/aeh025)

Rose CE Jr, Anderson RJ \& Carey RM 1984 Antidiuresis and vasopressin release with hypoxemia and hypercapnia in conscious dogs. American Journal of Physiology 247 R127-R134.

Russell JA 2011 Bench-to-bedside review: vasopressin in the management of septic shock. Critical Care 15 226. (doi:10.1186/cc8224)

Sato N, Kawano S, Kamada T \& Takeda M 1986 Hemodynamics of the gastric mucosa and gastric ulceration in rats and in patients with gastric ulcer. Digestive Diseases and Sciences 31 35S-41S. (doi:10.1007/ BF01309321)

Scheeren TW, Schwarte LA, Loer SA, Picker O \& Fournell A 2002

Dopexamine but not dopamine increases gastric mucosal oxygenation during mechanical ventilation in dogs. Critical Care Medicine 30 881-887. (doi:10.1097/00003246-200204000-00028)

Schwartges I, Schwarte LA, Fournell A, Scheeren TW \& Picker O 2008 Hypercapnia induces a concentration-dependent increase in gastric mucosal oxygenation in dogs. Intensive Care Medicine 34 1898-1906. (doi:10.1007/s00134-008-1183-8)

Schwartges I, Picker O, Beck C, Scheeren TW \& Schwarte LA 2010 Hypercapnic acidosis preserves gastric mucosal microvascular oxygen saturation in a canine model of hemorrhage. Shock 34 636-642. (doi:10.1097/SHK.0b013e3181e68422)

von Spiegel T, Wietasch G, Bursch J \& Hoeft A 1996 Cardiac output determination with transpulmonary thermodilution. An alternative to pulmonary catheterization? Der Anaesthesist 45 1045-1050. (doi:10.1007/s001010050338)

Temmesfeld-Wollbruck B, Szalay A, Mayer K, Olschewski H, Seeger W \& Grimminger F 1998 Abnormalities of gastric mucosal oxygenation in septic shock: partial responsiveness to dopexamine. American Journal of Respiratory and Critical Care Medicine 157 1586-1592.

Trzeciak S, McCoy JV, Phillip Dellinger R, Arnold RC, Rizzuto M, Abate NL, Shapiro NI, Parrillo JE \& Hollenberg SM 2008 Early increases in microcirculatory perfusion during protocol-directed resuscitation are associated with reduced multi-organ failure at $24 \mathrm{~h}$ in patients with sepsis. Intensive Care Medicine 34 2210-2217. (doi:10.1007/s00134-0081193-6)

Received in final form 13 January 2013

Accepted 28 January 2013

Accepted Preprint published online 28 January 2013
(C) 2013 Society for Endocrinology Printed in Great Britain 